\title{
Evidence for the Involvement of Pathogenic Bacteria in Summer Mortalities of the Pacific Oyster Crassostrea gigas
}

\author{
M. Garnier ${ }^{1}$, Y. Labreuche ${ }^{1}$, C. Garcia ${ }^{2}$, M. Robert ${ }^{2}$ and J.-L. Nicolas ${ }^{1}$
}

(1) UMR-PE2M, Ifremer, Centre de Brest, BP 70, 29280 Plouzané, France

(2) LGP, Ifremer, 17390 La Tremblade, France

*: Corresponding author : jlnicola@ifremer.fr

\begin{abstract}
:
A study was conducted to investigate the involvement of bacteria in oyster mortalities during summer. Moribund and apparently healthy oysters were sampled during mortality events along the French coast and in rearing facilities, usually when temperature reached $19^{\circ} \mathrm{C}$ or higher, and oysters were in the gonadal maturation phase. Hemolymph samples were aseptically withdrawn and submitted to bacteriological analysis. In healthy oysters, bacteria colonized hemolymph at low concentrations depending on the location. In most moribund oysters, bacteria were present in hemolymph and other tissues. These bacterial populations were more often diverse in oysters originating from the open sea than from facilities where animals were generally infected by a single type of bacterium. Only the dominant colonies were identified by phenotypic and genotypic characters (RFLP of GyrB gene and partial sequence of $16 \mathrm{~S}$ rRNA gene). They belonged to a limited number of species including Vibrio aestuarianus, members of the $\mathrm{V}$. splendidus group, $\mathrm{V}$. natriegens, $\mathrm{V}$. parahaemolyticus, and Pseudoalteromonas sp. The most frequently encountered species was $\mathrm{V}$. aestuarianus $(56 \%$ of isolates), which was composed of several strains closely related by their 16S rRNA gene but diverse by their phenotypic characters. They appeared intimately linked to oysters. The species within the $\mathrm{V}$. splendidus group were less prevalent (25\% of isolates) and more taxonomically dispersed. A majority of the dominant strains of $\mathrm{V}$. aestuarianus and $\mathrm{V}$. splendidus group injected to oysters induced mortality, whereas others belonging to the same species, particularly those found in mixture, appeared innocuous.
\end{abstract}




\section{INTRODUCTION}

The Pacific oyster Crassostrea gigas is regularly subjected to mortality during summer. This phenomenon has been observed for a long time in different countries including Japan, USA and Brazil (25,26,27). In France, since 1991, high Crassostrea gigas spat mortality rates (60 to $100 \%$ ) have been reported during summer, and are of major concern to oyster farmers (4, 34). Several hypotheses concerning the etiology of these summer mortalities have been explored. In all these cases, mortalities occurred when temperature rose above $18^{\circ} \mathrm{C}$ and during the reproduction period $(3,4,27,29)$. However, numerous other factors could be involved in these mortalities, which can be very rapid and last over several weeks. According to the method of investigation and the area considered, some factors have been shown either to start mortalities or to favor them. Stressful conditions, due to low dissolved oxygen, harmful algae, pollutants or toxic substances released by sediment for instance, could set off the mortality, whilst management practices, oyster genetic origin, phytoplankton quantity and quality might modulate the extent of mortality $(7,25,27,34)$. The hypothesis of infection by pathogens has not been considered the most probable, although tissues were sometimes colonised by parasites, viruses or bacteria $(3,26)$. The frequency of pathogenic agents seemed generally low in oysters affected by summer mortality, except in some areas such as Chesapeake Bay $(8,7,15)$.

Known infectious diseases in spat, juvenile or adult oysters are mainly caused by viruses (OshV 1: Oyster herpes virus type 1 in spat, iridovirus) or protozoans, including Haplosporidium spp. and Perkinsus spp. (12). They can generally be diagnosed by histological examinations which allow recognition of pathogenic agents (except viruses) and typical lesions of certain viruses.

In France, OshV 1 is regularly diagnosed (31) in dying juveniles ( $<1$ year), especially when temperature rises quickly. However, this pathogenic agent can explain only some cases of summer mortality (32). Most reported bacterial diseases occur mostly during the larval stages and only some are found in juveniles and adults $(10,11,12)$. The main bacterial diseases described in oysters, $C$. virginica, are juvenile oyster disease (JOD) and nocardiosis $(14,5,15)$. In JOD, different bacteria including Vibrio $s p$ and Roseobacter $s p$ were demonstrated to be involved in the disease which also involves a complex of interactions with environmental factors. It occurs when temperature reaches $20^{\circ} \mathrm{C}$ but it is not linked to the maturation phase. The described symptoms of JOD, i.e. conchiolin deposit and shell abnormalities (14), differ from symptoms of summer mortalities. During summer mortalities of that species, Beattie et al. (2) observed severely affected animals which exhibited different symptoms as pustules in mantle and invasion of tissues by a gram variable bacterium, later identified by Friedman et al. (15) as Nocardia crassostrea.

However, the relationship between summer mortality and potential infection by pathogenic agent was first established by Lipp et al. (24). These authors showed that hemolymph of moribund oysters contained a consistently high load of vibrios, of which some could provoke oyster mortalities by injection at elevated temperature. More recently, Lacoste et al. (20) attributed the cause of summer mortality of C. gigas in Bay of Morlaix, France, to an infection by Vibrio splendidus. Other authors (35) isolated a strain of $V$. chagasii, previously named $V$. splendidus type II, from moribund spat in one mortality case and reproduced mortality by means of experimental challenge. Finally, Gay et al. (19) demonstrated the pathogenicity to oysters of strains of $V$. splendidus group isolated during mortality events. Thus, different Vibrio species, notably those of the $V$. splendidus group, might be involved in summer mortalities, but a study of their occurrence in oysters is lacking. We report here the results of a 3-year study (2001 to 2003), which was conducted within the framework of the Morest (summer mortality) program in France to investigate the involvement of bacteria 
in oyster mortalities. Juvenile and adult oysters were maintained in onshore facilities or in tidal areas in bags. During mortality episodes, both moribund and apparently healthy oysters were collected and their hemolymph was submitted to bacteriological analyses.

\section{MATERIALS AND METHODS}

\section{Sampling and bacterial analyses}

Oysters exhibiting mortality in some oyster farms and in experimental facilities (hatchery of Argenton and nursery of Bouin) along the French coast were sampled over 3 years (2001 to 2003) (Fig. 1). The mortality could be rapid or be spread over some weeks. The majority of collected oysters were originatedd from experiments in the Morest program in the open sea and in research facilities. The others (one third) were collected from oyster farmers for zoosanitary monitoring (REPAMO). Forty two percent of moribund individuals were collected in the hatchery (Argenton) or nursery (Bouin) and 58\% came from field-deployed oysters bags. Samples from the field were collected from June to October. They came mainly from the Atlantic coast and the Bay of Veys in Normandy (Fig. 1). Moribund oysters were collected from 14 mortality episodes in 2001, 7 in 2002, and 6 in 2003. In experimentally deployed oyster bags, animals were about 18 month old, whereas in oyster farms, they were generally younger ( $<1$ year), except in the Bay of Veys where they were 2 to 4 years old. In the Argenton hatchery they ranged from 5 months to 3 years. In facilities, the observation and sampling of oysters could be done every day whereas in the field, animals could only be visited about every other week, depending on the tide. Immediately after collection oysters were placed at $4^{\circ} \mathrm{C}$ and analyzed after either 2 or 24 hours, depending on the proximity of the sampling location to the laboratory. From 1 to 10 moribund oysters (3.7 oysters on average) along with at least 5 apparently healthy oysters collected in the field were analysed per mortality event except in 2 samples in Bay of Veys when only nonmoribund oysters were available for analysis. In hatchery or nursery facilities, only moribund oysters were examined. Some juvenile oysters $(<1$ year), were assayed for herpesvirus type 1 (OsHV 1) by REPAMO according to the PCR method described by Arzul et al. (1).

Throughout the study, 190 apparently healthy and 109 diseased oysters were examined and individually analysed by bacteriological methods. Hemolymph samples were withdrawn from the adductor muscle or pericardial cavity through a notch in the shell using a $1 \mathrm{~mL}$ syringe fitted with a 23-gauge needle. Particular care was taken to avoid contaminating the sample with pallial cavity fluid. An aliquot of hemolymph was examined by light microscopy to check for the presence of bacteria. Another aliquot was subjected to a ten-fold serial dilution and $0.1 \mathrm{~mL}$ of the last dilution was plated onto Marine Agar (Difco). After 2, 3 or 5 days of incubation at $20^{\circ} \mathrm{C}$, the different types of colonies were separately counted. The morphology of each type was determined by size, shape, and colour. When one type constituted at least $30 \%$ of all colonies, it was purified by subculture and kept at $-80^{\circ} \mathrm{C}$. They were cultured again to be characterised by phenotypical and genotypical characters as described below. This analysis was not performed unless a morphological type reached this proportion.

\section{Histology.}

During a hatchery mortality episode, a histological diagnosis for $V$. aestuarianus was done on several oysters. The soft tissues of 20 diseased (moribund and apparently healthy) oysters were fixed in Davidson's fixative, dehydrated through an ascending ethanol series, cleared in 
xylene, embedded in paraffin, sectioned at 3-4 $\mathrm{mm}$ thickness, stained with hematoxylin and eosin, and carefully checked for the presence of lesions and pathogens.

\section{Genotypic identification}

The homogeneity of isolates by type of colony was checked by PCR-RFLP of GyrB gene. The $g y r B$ gene was chosen because it is more discriminating than the SSU-RNA gene (21). Bacterial strains were cultured overnight in Marine Broth (Difco) at $20^{\circ} \mathrm{C}$. Nucleic acids were extracted according to Gauthier et al. (18). Amplification of gyrB gene was subsequently performed following the method described by Yamamoto \& Harayama (37) using the primers UP-1E (5'- CAG GAA ACA GCT ATG ACC AYG SNG GNG GNA ART TYR A CAG GAA ACA GCT ATG ACC-3') and APrU (5'-TGT AAA ACG ACG GCC AGT GCN GGR TCY TTY TCY TGR CA TGT AAA ACG ACG GCC AGT-3’ ). After denaturation of the DNA template at $95^{\circ} \mathrm{C}$ for $3 \mathrm{~min}, 30$ cycles were run as follows: denaturation at $94{ }^{\circ} \mathrm{C}$ for 30s, annealing at $58{ }^{\circ} \mathrm{C}$ for $1 \mathrm{~min}$, and elongation at $72{ }^{\circ} \mathrm{C}$ for 90s. A final elongation step of $10 \mathrm{~min}$ at $72{ }^{\circ} \mathrm{C}$ was performed. Polymorphism among PCR products were determined using the restriction enzyme Hha1 according to the manufacturer instructions. After enzymatic digestion, the resulting restriction fragments were analysed eclectrophoretically on $1 \%$ agarose gel. The $16 \mathrm{~S}$ rRNA gene of isolates representing the main fingerprints was sequenced.

For amplification of the SSU-RNA gene, the same protocol was used with the primers AS dir (5'-AGA GTT TGA TCA TGG CTC AGA-3') and S17 rev (5'-GTT ACC TTG TTA CGA CTT-3'). The annealing temperature was $52^{\circ} \mathrm{C}$. Amplified products were cloned using Topo TA cloning-System (Invitrogen). Minipreps of recombinant plasmids were prepared according to standard alkaline lysis protocols with an additional phenol/chloroform extraction step and ethanol precipitation. Sequencing was performed by Genome Express, Grenoble, France.

The 16S rRNA gene sequences were aligned using the Megalign programme (Dnastar, Madison, Wisconsin, USA) with the nearest reference sequences, obtained from Blast analysis using the Clustal W programme. Phylogenetic trees were built with the Phylowin programme (17) using the Neighbour-Joining method.

\section{Phenotypic identification}

Phenotypic characters of select isolates were determined in using API 20E identification kit (Biomérieux) with $20 \mathrm{~g} \mathrm{~L}^{-1} \mathrm{NaCl}$ added to the suspension medium.

Numerical analysis of phenotypic characters was performed using simple matching coefficients and an unweighted pair group method (33).

\section{Experimental reproduction of bacterial diseases}

One and half to 2 years old of animals (shell height from 9 to $12 \mathrm{~cm}$ ) were acclimatedin seawater at $19^{\circ} \mathrm{C}$ for at least two days before experiments.

Predominant bacteria isolated from diseased oyster, were cultured in Marine Broth at $20^{\circ} \mathrm{C}$ for $24 \mathrm{~h}$ under agitation (180 rpm). Bacterial cells were subsequently collected by centrifugation (6000g, 10min) rinsed with sterile seawater (SSW) and resuspended in SSW. The O.D. of bacterial suspension was measured at $540 \mathrm{~nm}$. Bacterial cell concentration was estimated using a cell number-optical density $(540 \mathrm{~nm})$ relationship previously established.

A $0.1 \mathrm{~mL}$ volume of the bacterial suspension $\left(10^{7}\right.$ or $10^{8}$ per individual according to the experiment) was injected into the adductor muscle of each animal in the treatmen group $(n=30)$. Each oster in the control group $(n=30)$ was similarly injected with $0.1 \mathrm{~mL}$ of sterile 
seawater. Immediately after injection, oysters were transferred to 30-L tanks containing aerated filtered seawater at ambient temperature $\left(20 \pm .1^{\circ} \mathrm{C}\right)$ and kept under static conditions. Seawater was changed and algae ( Isochrysis affinis galbana clone T-iso and Pavlova lutheri about $10^{5}$ cell $\mathrm{mL}^{-1}$ final concentration) was added twice a week. Mortalities were observed every day for 10 days after injection. Hhemolymph of dying oyster was streaked onto MA agar to determine if the infectious bacteria corresponded to the inoculated bacteria. That was assessed by the colony morphology and by PCR-RFLP of the gyrB gene

\section{RESULTS}

\section{Identification and frequency of bacteria}

Two hundred and fifty six isolates were analysed by RFLP-gyrB. They were isolated mainly from dying oysters because in apparently healthy oysters the bacterial populations were generally weakly concentrated and too diversified to be analysed. Then, the 16S rRNA gene of 23 isolates representing the $80 \%$ of fingerprints, what included $96 \%$ of strains, was sequenced. After phylogenetic analysis (Figs. 2 and 3), they were clustered in two genera Pseudoalteromonas and Vibrio. Most of Vibrio strains were affiliated to some closely related species: $V$. aestuarianus, $V$. natriegens and to the group of $V$. splendidus. Pseudoalteromonas isolates constituted 3 species of which one belonged to P. atlantica, and the other two were not affiliated with a reference species. Only some sequences of $V$. aestuarianus strains such as 01/308, 01/114, 01/067, 01/151 isolated at different periods and/or in different sites, were perfectly identical.

Vibrio aestuarianus was the most frequently isolated species (56\%), followed by the $V$. splendidus group at $25 \%$, Pseudoalteromonas $s p$. at $12 \%$, and $V$. natriegens at $6 \%$ (Fig.5). The phenotypic characters of isolates identified as belonging to the same species by their $16 \mathrm{~S}$ rRNA gene were diverse. In numerical taxonomy, these isolates were clustered by species, but they were scattered in different taxons of the dendrogram (Fig.4). When the phenotypic identification of the same isolates was done again, some characters such as indole, citrate, ONPG (Ortho Nitrophenyl GalactoPyranoside), gelatinase and acidification of organic compounds (glucose, mannitol, sorbitol) could change although the method remained identical: exponential phase, salinity, time and temperature of incubation. Consequently this relative fickleness of phenotypes prevented an accurate identification of these vibrios by the methods we employed.

\section{Bacterial occurrence in oysters.}

The moribund oysters examined during the mortality episodes can be classified in different categories (Table 1) according to the bacterial concentration and diversity in hemolymph

- Oyster infected by only one bacterial strain at high concentrations $\left(>10^{7} \mathrm{~mL}^{-1}\right)$ and generally the same in all animals analyzed in a single episode. This was mainly observed in the Argenton hatchery, the Bouin nursery and in the Bay of Veys in October 2001 and May. 2002. They represented 51.3\% of analysed oysters.

- Oysters infected with high concentrations $\left(>10^{7} \mathrm{~mL}^{-1}\right)$ of 10 or more strains. This occurred most frequently in field-deployed oyster bags and represented $28.4 \%$ of analysed oysters.

- Oysters (2.7\%) infected with a single bacterial strain at intermediate concentrations $\left(10^{5} \mathrm{~mL}^{-1}\right.$ to $\left.10^{6} \mathrm{~mL}^{-1}\right)$. These represented $2.7 \%$ of analysed oysters and were found at Fouras and the Bay of Veys. 
- Oyster (9.2\%) infected by several bacterial strains at intermediate concentrations $\left(10^{5} \mathrm{~mL}^{-1}\right.$ to $\left.10^{6} \mathrm{~mL}^{-1}\right)$. These represented $9.2 \%$ of all analysed oysters and were found at the Bay of Veys, Arcachon, and Quiberon.

- Oyster dying with a low level of bacteria or without. These were found at Arcachon, Quiberon, the Gulf of Morbihan, and Marennes Oléron Bay and constituted 8.3\% of analysed oysters.

The apparently healthy oysters could be classified in the same categories, but their proportions were reversed. Most apparently healthy oysters were not infected (66.3\%) but some were invaded by several bacterial strains $(15.3 \%)$ and in a few cases by only one bacterial strain (1.1\%). Most of oysters with septicaemia came from Fouras, a location where all oysters in June 2001 were heavy charged in bacteria. The others exhibited middle concentrations of bacteria with one type (4.7\%) or several (12.6\%).

Every event of mortality was described in tables 2 and 3. No correlation appeared between the prevalence of mortality and age. However the oysters in the field were relatively young. Whilst in hatchery the oyster died at any age (from 3 months to 3 years).

When a mixture of bacteria invaded hemolymph, strains of $V$. splendidus was the most frequently isolated .and V. aestuarianus was found just twice. Pseudoalteromonas strains colonized hemolymph in 3 cases out of 16 for oysters in the field but they did not seem pathogenic. In the hatchery the only one strain of Pseudoalteromonas sp. (03/034) found was virulent. Although the herpes virus was analysed in a few case it was detected only in 2 cases out of 6 .

\section{Experimental infection.}

No significant difference in mortality was observed between inocula of $10^{7}$ or $10^{8}$ cells per oyster-. The only strains determined to be pathogenic in laboratory challenge were those that were predominant in moribund oysters (Tables 2 and 3). Strains isolated from mixtures were not pathogenic $(01 / 070,01 / 097,01 / 104,01 / 108,01 / 110,01 / 127,01 / 131,01 / 252)$ or only weakly pathogenic (01/046).

Strains of $V$. aestuarianus were isolated mainly as the predominant bacterium in dying oysters. The strains 01/026, 01/031, 01/032, 011/067, 01/323, 02/041, 02/093, 02/103, 03/010 and 03/015 isolated from Argenton, Bouin and Bay of Veys sites were virulent. However, the others were less so $(01 / 064,01 / 151)$ or not at all $(01 / 308,01 / 312,02 / 114)$. Among 4 strains of $V$. splendidus isolated as single or predominant species and tested, 3 (01/046, 02/069, 03/012) appeared virulent but the fourth $(01 / 083)$ was not. A Pseudoalteromonas species (03/034) isolated as predominant species resembling $P$. piscicida exhibited a moderate virulence whilst other isolates of Pseudoalteromonas sp (01/110, 01/121), isolated from mixtures, were not pathogenic

\section{Description of disease, histology}

The main symptom exhibited by the diseased oyster in experimental or natural infection is weakness of the adductor muscle. The valves closed more and more slowly and when oysters were unable to close their valves, they were considered to be dead. Inside the shell, no particular sign such as conchyolin deposit or necrosis and degradation of the hinge was observed.

Histological examination of infected oysters showed that all tissues appeared more or less degraded with necrosis and particularly the muscle fibers, which were disorganized and necrosed. Bacteria invaded all tissues, especially connective and conjunctive tissues, and were not clustered in microcolonies, but were dispersed. 


\section{DISCUSSION}

Although the mortality events occurred in different locations along the coast and in facilities, this 3-year study demonstrated that they were very often associated with the bacteraemia in hemolymph. The validity of these results depends on the quality of analysed animals. Some difficulties were encountered in collecting the dying oysters in the field. Sometimes, analysis of apparently healthy oysters could compensate for the lack of moribund animals. However apparently healthy oysters, except in Bay of Veys were not infected and did not provide any indication on an eventual infection by bacteria. Moribunds were collected in 13 out of 15 mortality cases occurring in growout locations along the French coast. These episodes represented typical summer mortality events. The number of moribunds analysed by event was low and could not be considered as representative of all dead and dying oysters. However, the redundancy of bacterial species isolated from hemolymph allows us to infer that the occurrence of bacteria might be comparable in many more oysters than just those analysed. Dying oysters in hatcheries and nurseries may be more representative of diseased oysters since all of them could be taken with intact tissues and only one type of bacterium was typically observed. Most of the oysters in these facilities were maintained under conditions of temperature, food and gonadal maturation phase similar to those grown in open sea except seawater renewal was much more limited and could have promoted the dissemination of infectious agents.

In our study, bacteria were identified only if they were dominant in $30 \%$ or more of individuals. Phenotypic characters allowed differentiation of $V$. aestuarianus, V. natriegen, $V$ parahaemolyticus and $V$. splendidus group members although they differed considerably from one strain to another inside the same species. This variation could be due to versatility of bacteria since the same isolate showed different characteristics, as determined in replicate API 20E assays (results not reported here). A similar observation was made for $V$. parahaemolyticus, an ubiquitous bacterium, in which genetic rearrangements create additional phenotypic versatility (6).

Conversely, isolates identified by partial sequence of 16S rRNA gene were exclusively composed of a few species of Vibrio and sometimes of Pseudoalteromonas species. $V$. aestuarianus was isolated more frequently than the others in our study. The other isolates belonged mainly to the $V$. splendidus group. This group now contains 8 species (13) and only presumptive affiliation at the species level could be proposed with this preliminary identification.

How can bacteria enter and survive inside the soft tissues and fluids of oyster? It seems that any bacterium can easily reach the hemolymph at certain periods. The penetration of bacteria might be linked to the weakness of immune defence during maturation phase and the increase of bacterial population in the environment. Olfasen et al. (28) reported similar observations, and demonstrated the presence of bacteria in hemolymph and tissues of healthy bivalves. In $C$. gigas, at temperatures of 1 to $8^{\circ} \mathrm{C}$, bacterial concentrations reached about $10^{3}$ cells $\mathrm{mL}^{-1}$. In mussels, Mytilus edulis, they reached $2.9 \times 10^{4}$ per $\mathrm{mL}$ or g. In both cases, a variety of bacterial species were present, except when a bacterial strain was added at high concentration in a tank where oysters were maintained.

A study of the bacterial populations in the digestive tract, gonaducts, or in the pallial cavity would help determine if these Vibrio and Pseudoalteromonas species are persistent oyster symbionts before invading hemolymph and tissues. Puljate et al. (30) reported that members of $V$. splendidus group were predominant in oyster tissues growing in Mediterranean at temperature below $20^{\circ} \mathrm{C}$ and $V$. harveyi at higher temperature. 
When only one strain invaded the soft tissues, it could be considered as the primary cause of disease. Infection by only one bacterial species was found in $50 \%$ of mortality events in open-sea sites. In facilities mortality seemed systematically to be provoked by bacterial infection. ,Even if the virus herpes occurred in one case(Bouin, 12/06/02), pathogenic bacteria were also present. Most of tested dominant bacteria were virulent and only five were devoid of pathogenicity. These last strains could have lost their virulence after some subcultures but we did not observe any decrease of activity for the virulent strains. In contrast, most of tested isolates taken in the mixtures were not pathogenic. Possibly, the primary invaders had disappeared or were not septicemic and just located in some tissues. More probably, the physiological state of the oysters was compromised to the extent that they could be colonised by any saprophytic bacteria.

Other pathogenic agents than bacteria could also induce oyster mortality but the histological examinations of oysters during mortality cases performed by REPAMO for 8 years (C. Garcia personal communication) have never revealed the presence of parasites, such as Haplosporidium sp or virus, except OsHV1 in juveniles $(1,31)$. In several mortality events, the death of oysters in field growout locations might have been provoked by other causes than pathogens. The involvement of physical and chemical factors has been postulated: pollutants, toxic compounds released by sediment, lack of oxygen, and large temperature fluctuations that could stress animals in periods of fragile physiological condition (maturation period). For instance, mortality events at Arcachon (26/06/01), Fouras (19/06/01, 26/06/01) and Morbihan (28/06/01, 2/07/03) did not seem to be explained by bacterial or viral infection.

The temperature of $19^{\circ} \mathrm{C}-20^{\circ} \mathrm{C}$ (34) appears to constitute a threshold that triggers oyster summer mortality in France. Interestingly, however, at the Argenton hatchery, one case of infection by $V$. aestuarianus was observed at $9^{\circ} \mathrm{C}$ in tetraploid oysters. Moreover, in the Bay of Veys, mortalities with septicaemia of $V$. aestuarianus started when temperature reached $19^{\circ} \mathrm{C}$ in September during the maturation phase but they lasted when temperature declined to $16^{\circ} \mathrm{C}$ in October. In the same location, one mortality episode started in May at $13^{\circ} \mathrm{C}$, with pathogenic bacteria belonged to V. splendidus group. Although the temperature of $19-20^{\circ} \mathrm{C}$ certainly favoured the growth of vibrios and the sensitivity of oysters, but it did not seem to be absolutely necessary to induce bacterial infection.

Finally, the impact of opportunistic/pathogenic bacteria on oyster mortality must be evaluated for each case. If just one bacterial strain can be isolated at high concentration in several animals, it may be concluded that it could be implicated in the mortality. They may amplify the summer mortality at least and probably start mortality as observed in experimental hatchery and nursery. Conversely the real impact of invasive bacteria found in mixture, remains to be evaluated. Co-infection should be performed to verify if several bacteria can act in collaboration to induce disease (19).

In conclusion to evaluate the real impact of pathogenic bacteria in comparison with other causes will remain impossible. Indeed the three elements, pathogen, environment, physiological status of the host strongly interact in this disease. In some cases only two unfavourable elements seem sufficient to provoke mortality but generally the three cooperate to provoke mortality. The incidence of bacteria appeared particularly important when the mortality lasted several weeks (Bay of Veys and in facilities) and perhaps more restricted when outbreak of disease stopped after some days, except in spat from nursery (Bouin).

When juvenile and adult oysters die in the hatchery, bacterial involvement should be considered in the same manner as OsHV1 is for seed (24). They could be at the origin of numerous cases of mortality in facilities and persist after transfer to growout areas where the 
seed could disseminate the bacteria to nearby oysters. Therefore, it would be valuable to determine the presence of these types of vibrios before transfer to avoid placing contaminated seed in field locations.

\section{Acknowledgements:}

The authors are indebted to Susan Ford (USA) for the critical review of the manuscript and for his help in editing the English language.

This work was supported by the MOREST national project funded by Ifremer and by the Regions, Basse-Normandie, Bretagne, Pays de la Loire and Poitou-Charentes and the Conseil Général du Calvados.

\section{References}

[1] Arzul I, Renault, T, Lipart, C (2001) Experimental herpes-like viral infections in marine bivalves: demonstration of interspecies transmission. Dis Aquat Organ 46: 1-6

[2] Beattie, H, Elston, R, Friedman, C, Hedriels, R (1988) Geographically widespread bacterial infection and mortality in Pacific oysters, Crassostrea gigas. J Shellfish Res 7: $109-110$

[3] Beattie, JH, Chew, KK (1981) Some relationships between gametogenetic cycle and summer mortality phenomenon in the Pacific oyster Crassostrea gigas in the Washington state. J Shellfish Res 1: 9-16

[4] Berthelin, C, Kellner, K, Mathieu, M (2000) Storage metabolism in the Pacific oyster (Crassostrea gigas) in relation to summer mortalities and reproductive cycle (west coast of France). Comp Biochem Physio 1125: 359-369

[5] Boettcher, KJ, Barber, BJ, Singer, JT (2000) Additional evidence that juvenile oyster disease is caused by a member of the Roseobacter group and colonization of nonaffected animals by Stappia stellulata-like strains. Appl Environ Microbiol 66 :3924-3930

[6] McCarter, LJ (1999) The multiple identities of Vibrio parahaemolyticus. Mol Microbiol Biotechnol 1:51-57

[7] Cheney, DP, Macdonald, BF,_Elston, RA (2000) Summer mortality of Pacific oysters, Crassostrea gigas (Thunberg): Initial findings on multiple environmental stressors in Puget Sound, Washington, 1998. J Shellfish Res 19:353-359

[8] Chu, FE, Volety, AK, Constantin, GA (1996) Comparison of Crassostrea gigas and Crassostrea virginica: Effects of temperature and salinity on susceptibility to the protozoan parasite, Perkinsus marinus. J Shellfish Res 15: 375-380

[9] Degremont, L.,.Boudry, P, Soletchnick, P, Bedier, E, Ropert, M; Huvet, A, Moal, J, ;.Samain, JF (2003) Genetic basis of summer mortality in juvenile cupped oysters. J. Shellfish Res... 22, :.327. (abstract) 
[10] Dungan, CF, Elston, RA (1988) Histopathological and ultrastructural characteristics of bacterial destruction of hinge ligaments of cultured juvenile Pacific oysters, Crassostrea gigas. Aquaculture. 72. 1-14

[11] Elston, R, Frelier, P, Cheney, D (1999). Extrapallial abscesses associated with chronic bacterial infections in the intensively cultured juvenile Pacific oyster Crassostrea gigas. Dis Aquat Org 37: 115-120

[12] Elston, RA (1993) Infectious diseases of the Pacific oyster, Crassostrea gigas Annu Rev Fish Dis 3, 259-276

[13] Faury, N, Saulnier, D, Thompson, FL, Gay, M, Swings, J, Le Roux, F (2004) Vibrio crassostreae sp. nov., isolated from the haemolymph of oysters (Crassostrea gigas). Int Syst Evol Micobiol 54: 2137-2140

[14] Ford, SE, Borrero, FJ (2001) Epizootiology and Pathology of Juvenile Oyster Disease in the Eastern Oyster, Crassostrea virginica. J Invertebr Pathol 78: 141-154

[15] Friedman, CS, Beattie JH, Elston, RA, Hedrick, RP (1991) Investigation of the relationship between the presence of a Gram-positive bacterial infection and summer mortality of the Pacific oyster, Crassostrea gigas Thunberg. Aquaculture. 94: 1-15

[16] Friedman, CS, Beaman, BL, Hedrick, RP, Beattie, JH, Elston, RA (1989) Nocardiosis of adult Pacific oysters, Crassostrea gigas. J Shellfish Res 8 : 321 (abstract)

[17] Galtier, N, Gouy, M, Gautier, C (1996) SEAVIEW and PHYLO_WIN: two graphic tools for sequence alignment and molecular phylogeny. Comput Appl Biosci 12: 543-548

[18] Gauthier G, Lafay, B, Ruimy, R, Breittmayer, V, Nicolas, JL, Gauthier, M, Christen, R (1995) Small-subunit rRNA sequences and whole DNA relatedness concur for the reassignment of Pasteurella piscicida (Snieszko et al.) Janssen and Surgalla to the genus Photobacterium as Photobacterium damsela subsp. piscicida comb. nov.. Int J Syst Bacteriol 45:139-144

[19] Gay M, Berthe, FC, Le Roux, F (2004) Screening of Vibrio isolates to develop an experimental infection model in the Pacific oyster Crassostrea gigas Dis Aquat Organ 59::49-56

[20] Lacoste, A, Jalabert, F, Malham, S, Cueff, A, Gilbert, F, Cordevant, C, Lange, M, Poulet, SA (2001) A Vibrio splendidus strain is associated with summer mortality of juvenile oysters Crassostrea gigas in the Bay of Morlaix (North Brittany, France). Dis Aquat Org 46: 139-145

[21] Le Roux, F, Gay, M, Lambert, C, Nicolas JL, Gouy, M, Berthe, FCJ (2004) Phylogenetic study and identification of Vibrio splendidus related strains based on gyrB gene sequences. Dis Aquat Org 58: 143-150

[22] Le Roux, F, Gay, M, Lambert, C, Waechter, M,. Poubalanne, S, Chollet, B, Nicolas, JL, Berthe, FCJ (2002) Comparative analysis of Vibrio splendidus-related strains isolated during Crassostrea gigas mortality events. Aquat Living Resour 15: 251-258 
[23] Lipart, C, Renault, T (2002) Herpes-like virus detection in infected Crassostrea gigas spat using DIG-labelled probes.$\cdot J$ Virol Methods 101:1-10

[24] Lipp, PR, Brown, B, Liston, J, Chew, K (1976) Recent findings on the summer diseases of Pacific oysters. Proc Nat Shellfish Assoc 65: 9-10

[25] Lypowsky, VP, Chew, KK (1972) Mortality of Pacific oysters C. gigas: the influence of temperature and enriched seawater on survival. Proc Nat Shellfish Assoc 62:72-82

[26] Meyers, TR, Short, S, Eaton, W (1990) Summer mortalities and incidental parasitisms of cultured Pacific oysters in Alaska. J Aquat Ani Health 2: 172-176

[27] Mori, K, Imai, T, Toyoshima, K, Usui, I (1965) Studies on the Mass Mortality of the Oyster in Matsushima Bay IV. Changes in the physiological activity and the glycogen content of the oyster during the stages of sexual maturation and spawning. Bull Tohoku Reg Fish Res 25: 49-64

[28] Olafsen, JA, Mikkelsen, HV, Giaever, HM, Hansen, GH (1993) Indigenous bacteria in hemolymph and tissues of marine bivalves at low temperatures. Appl Environ Microbiol 59:1848-1854

[29] Perdue, JA, Erickson, G (1984) A comparison of the gametogenic cycle between the Pacific oyster Crassostrea gigas and the Suminoe oyster Crassostrea rivularis in Washington State. Aquaculture 37: 231-237

[30] Pujalte MJ, Ortigosa, M, Macian, MC, Garay, E (1999) Aerobic and facultative anaerobic heterotrophic bacteria associated to Mediterranean oysters and seawater. Int Microbiol 2: 259-266

[31] Renault, T, Lipart, C, Arzul, G (2001) A herpes-like virus infecting Crassostrea gigas and Ruditapes philippinarum larvae in France. J Fish Dis 24, 369-376

[32] Renault, T, Le Deuff, RM, Cochennec, N, Chollet, B. Maffart, P (1995) Herpes-like viruses associated with high mortality levels in larvae and spat of Pacific oysters, Crassostrea gigas: A comparative study, the thermal effects on virus detection in hatcheryreared larvae, reproduction of the disease in axenic larvae. Vet Res 26 : 539-543

[33] Sneath, PHA, Sokal, RR (1973) Numerical taxonomy: the principles and practice of numerical classification, Freeman WH, San Francisco, pp 1288-1308

[34] Soletchnik, P, Le Moine, O, Faury, N, Razet, D, Geairon, P; Goulletquer, P (1999) Summer mortality of the oyster in the Bay Marennes-Oleron: Spatial varaiability of environnement and biology using a geographical information system (GIS). Aquat Living Resour 12: 131-143

[35] Waechter, M, Le Roux, F, Nicolas, JL, Marissal, E, Berthe, F (2002) Characterisation of Crassostrea gigas spat pathogenic bacteria. C R Biologies 325:.231-238 
[36] Yamamoto S, Harayama, S (1995) PCR amplification and direct sequencing of gyrB genes with universal primers and their application to the detection and taxonomic analysis of Pseudomonas putida strains. Appl Environ Microbiol 61:1104-1109 


\begin{tabular}{|c|c|c|c|c|c|}
\hline & $\begin{array}{c}\text { Septicaemia } \\
\text { with } 1 \text { predominant } \\
\text { type } \\
\end{array}$ & $\begin{array}{c}\text { Septicaemia } \\
\text { with }>5 \text { types }\end{array}$ & $\begin{array}{c}\text { Bacteraemia } \\
10^{5}-10^{6} \mathrm{~mL}^{-1} \text { with } 1 \\
\text { predominant type }\end{array}$ & $\begin{array}{c}\text { Bacteraemia } 10^{5}-10^{6} \mathrm{~mL}^{-1} \\
\text { with }>5 \text { types }\end{array}$ & $\begin{array}{l}\text { Bacterial concentration } \\
<10^{5} \mathrm{~mL}^{-1}\end{array}$ \\
\hline Healthy (H) & 2 (Fou) & 28 (Fou), 1(MOB) & 1(GoM), 8(BoV) & $\begin{array}{c}2 \text { (Arc), 3(GoM), 7(BoV); } \\
\text { 6(MOB), } 6 \text { (Qib) }\end{array}$ & $\begin{array}{c}12(\mathrm{Arc}), 24(\mathrm{GoM}) \\
\text { 57(BoV), 29(MOB),; 6(Qib) }\end{array}$ \\
\hline Moribund (M) & $\begin{array}{c}\text { 25(Arg), 3(GoM), } \\
\text { 8(BoV), 19(Bou) } \\
\text { 1(MOB) }\end{array}$ & $\begin{array}{c}12 \text { (Fou), } 2 \text { (GoM), } \\
\text { 5(MOB), 4(Bou), } \\
\text { 1(BoV), 1(Qib), } \\
\text { 1(Arc), } 5 \text { (Arg) }\end{array}$ & 1(Fou), 2(BoV) & $\begin{array}{c}\text { 1(Arc), 4(BoV), 2(Qib), } \\
\text { 3(GoM) }\end{array}$ & 4(Arc), 1(GoM), 4(MOB) \\
\hline Total H/M & $2 / 56$ & $29 / 31$ & $9 / 3$ & $24 / 10$ & $126 / 9$ \\
\hline Healthy (\%) & 1.1 & 15.3 & 4.7 & 12.6 & 66.3 \\
\hline Moribund (\%) & 51.3 & 28.4 & 2.7 & 9.2 & 8.3 \\
\hline
\end{tabular}

Table 1: Repartition of apparently healthy or moribund oysters according to the type of bacterial invasion

Arc : Arcachon ; Arg : Argenton; : Bou : Bouin ; BoV : Bay of Veys: Fou : Fouras; : MOB: Marennes Oléron Bay ; Qib: Quiberon; GoM : Gulf of Morbihan 


\begin{tabular}{|c|c|c|c|c|c|c|c|c|}
\hline Location/ date & Temp. & mortality & Age of oyster & $\begin{array}{l}\text { analysed dying } \\
\text { oysters }\end{array}$ & $\begin{array}{c}\text { bacterial } \\
\text { Concentration }^{(1)}\end{array}$ & Identification of dominant strains ${ }^{(2)}$ & Virulence $^{(3)}$ & OsHV1 \\
\hline Fou $(12 / 06 / 01)$ & $18^{\circ} \mathrm{C}$ & $>30 \%$ & 11 months & 3 & $\mathrm{Hc}$ & $\begin{array}{l}\text { V. splendidus grp (01/046) } \\
\text { Pseudoalteromonas sp.(01/047) } \\
\text { V. aestuarianus (01/048) }\end{array}$ & $\begin{array}{c}+ \\
\text { nd } \\
\text { nd }\end{array}$ & + \\
\hline GoM(19/06/01) & $20^{\circ} \mathrm{C}$ & $30 \%$ & 1 year & 1 & $\mathrm{Hc}$ & V. aestuarianus (01/067) & ++ & nd \\
\hline Fou (19/06/01) & $19.5^{\circ} \mathrm{C}$ & $35 \%$ & 11 months & 1 & $\mathrm{Hc}$ & $\begin{array}{l}\text { V. splendidus grp (01/070) } \\
\text { V. splendidus grp (01/074) } \\
\text { V. splendidus grp (01/076) }\end{array}$ & $\begin{array}{l}- \\
\text { nd } \\
\text { nd. }\end{array}$ & - \\
\hline Arc $(26 / 06 / 01)$ & $21^{\circ} \mathrm{C}$ & $37 \%$ & 11 months & 6 & LC & $\begin{array}{l}\text { V. splendidus grp }(01 / 104) \\
\text { V. splendidus grp }(01 / 108) \\
\text { V. natriegens (01/097) } \\
\text { P. atlantica (01/110) }\end{array}$ & $\begin{array}{l}- \\
- \\
- \\
-\end{array}$ & - \\
\hline Fou $(26 / 06 / 01)$ & $19.5^{\circ} \mathrm{C}$ & 10 to $35 \%$ & 18 months & 9 & $\mathrm{Hc}$ & $\begin{array}{l}\text { V. aestuarianus (01/127) } \\
\text { V. splendidus grp }(01 / 131) \\
\text { V.aestuarianus (01/136) } \\
\text { Pseudoalteromonas sp. (01/121) }\end{array}$ & $\begin{array}{l}- \\
- \\
-\end{array}$ & nd \\
\hline GoM (28/06/01) & $20^{\circ} \mathrm{C}$ & $33 \%$ & 11 months & 3 & $\begin{array}{l}\mathrm{LC}(2) \\
\mathrm{Hc}(1)\end{array}$ & Too diversified & & - \\
\hline GoM (9/07/01) & $20^{\circ} \mathrm{C}$ & $35 \%$ & 1 year & 2 & $\mathrm{Hc}$ & V. aestuarianus (01/151) & + & - \\
\hline MOB (7/08/01 & $21^{\circ} \mathrm{C}$ & $20-40 \%$ & 6 months & 5 & $\mathrm{Hc}$ & $\begin{array}{l}\text { V. splendidus }(01 / 264) \\
\text { V.parahaemolyticus }(01 / 252) \\
\text { V. aestuarianus }(01 / 259)\end{array}$ & $\begin{array}{c}\text { nd } \\
- \\
\text { nd }\end{array}$ & nd \\
\hline BoV (27/08/01) & $19^{\circ} \mathrm{C}$ & $48 \%$ & 16 months & 0 & LC & V. aestuarianus (01/308) & - & nd \\
\hline BoV $(14 / 10 / 01)$ & $16^{\circ} \mathrm{C}$ & $35 \%$ & 18 months & 7 & LC & V. aestuarianus (01/312) & - & nd \\
\hline BoV (16/10/01) & $16^{\circ} \mathrm{C}$ & $20 \%$ & 2 years & 0 & LC & $\begin{array}{l}\text { V. aestuarianus }(01 / 322) \\
\text { V. splendidus }(01 / 323)\end{array}$ & $\begin{array}{c}- \\
+++ \\
++\end{array}$ & nd \\
\hline Qib (30/08/02) & $19^{\circ} \mathrm{C}$ & $30 \%$ & 2 years & 3 & LC & Too low concentration and too diversified & & nd \\
\hline $\operatorname{BoV}(5 / 09 / 02)$ & $19^{\circ} \mathrm{C}$ & $16 \%$ & 18 months & 2 & LC & V aestuarianus (02/103) & ++ & nd \\
\hline BoV (15/05/03) & $13^{\circ} \mathrm{C}$ & $20 \%$ & 2 years & 6 & $\mathrm{Hc}$ & V. splendidus grp (03/012) & ++ & nd \\
\hline MOB (25/06/03) & $22^{\circ} \mathrm{C}$ & $15 \%$ & 18 months & 5 & $\begin{array}{l}\mathrm{Hc}(1) \\
\mathrm{Lc}(4)\end{array}$ & V. aestuarianus $(03 / 015)$ & +++ & nd \\
\hline GoM (2/07/03) & $22^{\circ} \mathrm{C}$ & $25 \%$ & 18 months and & 3 & LC & Too low concentration and too diversified & & nd \\
\hline
\end{tabular}

Table 2 : Mortality events over 3 years of sampling in tidal areas.

(1) Lc: low concentration $\left(<10^{5}\right.$ cell $\left.\mathrm{mL}^{-1}\right)$; Hc: high concentration $\left(>10^{7}\right.$ cell $\left.\mathrm{mL}^{-1}\right)$. In parenthesis : number of oysters at low (LC) or high (Hc) concentration (2) Name of species: in bold characters the species was identified by 16S rRNA gene, in normal identified by RFLP gyrB, in parentheses the identification number of isolate.

(3) $+: 15-30 \%,++: 30-40 \%,+++:>40 \%$ mortality

For other legends see table 1. 


\begin{tabular}{|c|c|c|c|c|c|c|c|c|}
\hline Location/ date & Temp. & mortality & $\begin{array}{l}\text { Age of } \\
\text { oyster }\end{array}$ & $\begin{array}{c}\text { analysed dying } \\
\text { oysters }\end{array}$ & $\begin{array}{c}\text { bacterial } \\
\text { Concentration }^{(1)}\end{array}$ & $\begin{array}{l}\text { Identification of dominant } \\
\text { strains }^{(2)}\end{array}$ & Virulence $^{(3)}$ & OsHV1 \\
\hline $\operatorname{Arg}(23 / 03 / 01)$ & $20^{\circ} \mathrm{C}$ & $10 \%$ & $>2$ years & 3 & $\mathrm{Hc}$ & V. aestuarianus (01/026) & +++ & nd \\
\hline Arg (1/06/01) & $18^{\circ} \mathrm{C}$ & $30 \%$ & $>2$ years & 3 & $\mathrm{Hc}$ & $\begin{array}{l}\text { V. aestuarianus } \\
(01 / 032) \\
(01 / 031)\end{array}$ & $\begin{array}{c}+++ \\
++\end{array}$ & nd \\
\hline Arg (15/06/01) & $19^{\circ} \mathrm{C}$ & $35 \%$ & $>2$ years & 2 & $\mathrm{Hc}$ & V. aestuarianus (01/064) & + & nd \\
\hline $\operatorname{Arg}(25 / 06 / 01)$ & $19^{\circ} \mathrm{C}$ & $15 \%$ & $>2$ years & 2 & $\mathrm{Hc}$ & V. splendidus grp (01/083) & - & nd \\
\hline $\operatorname{Arg}(5 / 06 / 02$ & $19^{\circ} \mathrm{C}$ & $15 \%$ & 3 years & 6 & $\mathrm{Hc}$ & V. aestuarianus (01/041) & +++ & nd \\
\hline Bou $(12 / 06 / 02)$ & $20^{\circ} \mathrm{C}$ & $45 \%$ & 3 months & 5 & $\mathrm{Hc}$ & V. splendidus grp $(02 / 046)$ & nd & $\begin{array}{l}4 \text { positive } \\
\text { out of } 6\end{array}$ \\
\hline Bou (1/07/02) & $20^{\circ} \mathrm{C}$ & $40 \%$ & 4 months & 10 & $\mathrm{Hc}$ & V. splendidus grp (02/069) & ++ & - \\
\hline Bou $(23 / 07 / 02)$ & $20^{\circ} \mathrm{C}$ & $50 \%$ & 5 months & 8 & $\mathrm{Hc}$ & $V$ aestuarianus (02/093) & ++ & nd \\
\hline $\operatorname{Arg}(24 / 09 / 03)$ & $19^{\circ} \mathrm{C}$ & $10 \%$ & 2 years & 2 & $\mathrm{Hc}$ & $V$ aestuarianus (02/114) & - & nd \\
\hline $\operatorname{Arg}(25 / 02 / 03)$ & $9^{\circ} \mathrm{C}$ & $15 \%$ & $\begin{array}{c}2 \text { years } \\
\text { (tetraploïds) }\end{array}$ & 2 & $\mathrm{Hc}$ & $V$ aestuarianus (02/006) & nd & nd \\
\hline $\operatorname{Arg}(12 / 05 / 03)$ & $19^{\circ} \mathrm{C}$ & $10 \%$ & 2 years & 5 & $\mathrm{Hc}$ & V aestuarianus (03/010) & nd & nd \\
\hline Arg (17/08/03) & $20^{\circ} \mathrm{C}$ & $10 \%$ & 2 years & 5 & $\mathrm{Hc}$ & Pseudoalteromonas sp. (03/034) & ++ & nd \\
\hline
\end{tabular}

Table 3: Mortality events over 3 years of sampling in facilities For legends see the table 2. 
Figure 1. Location of $C$ gigas samples in open sea and in facilities during mortality between 2001 to 2003.

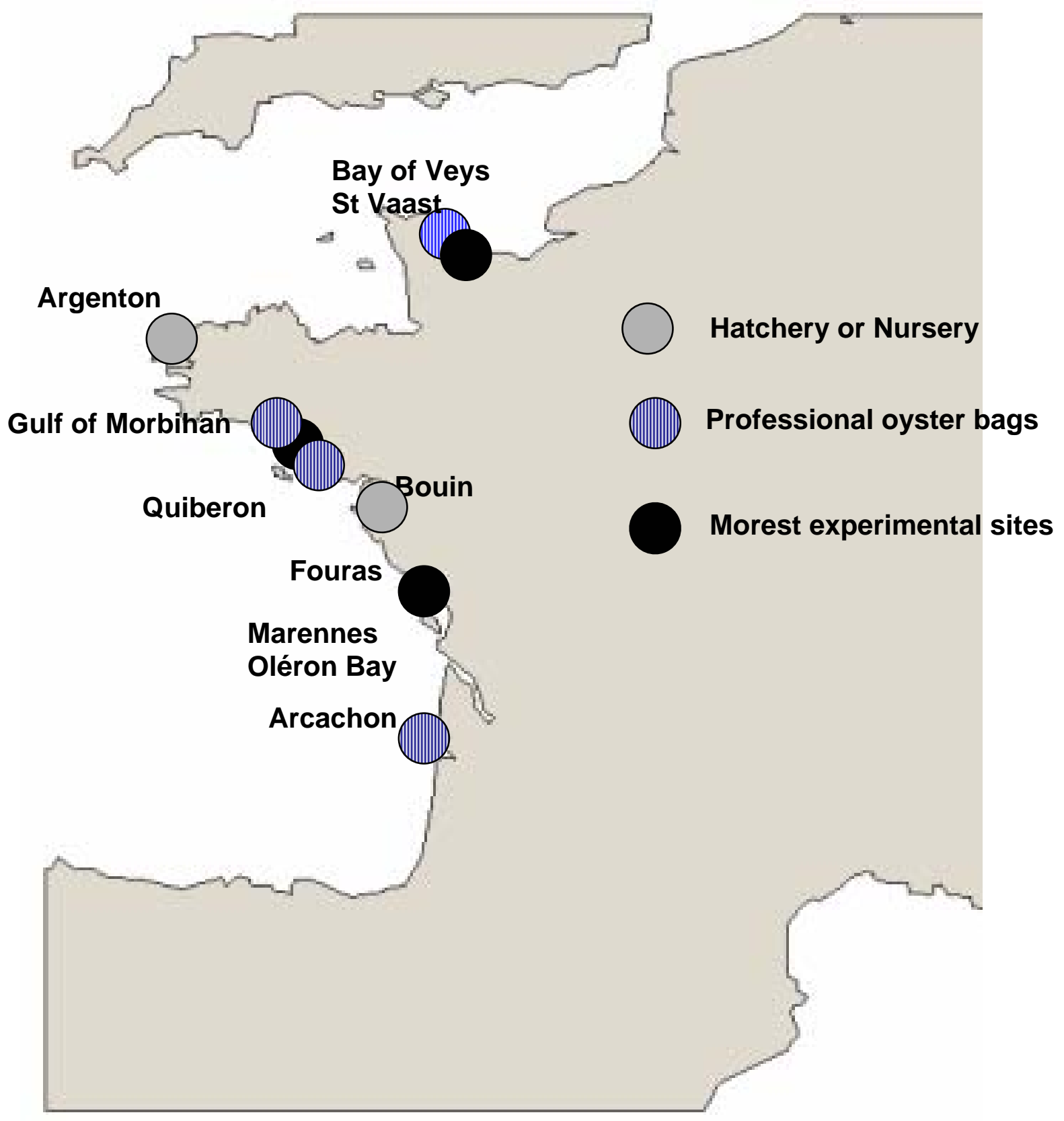


Figure 2 : Neighbour-joining tree (global gap removal, mean length 1146) representing the phylogenetic relationship among partial sequences of Vibrio isolated from oyster hemolymph and reference Vibrio from EMBL sequences data bank. Bootstrap values (500 replicates) greater than $50 \%$ are indicated. Accession numbers of EMBL sequences are given following the name of the isolate. The isolates are identified by 5 figures: The first two figures indicates the year and the tree following figures indicate the isolate number

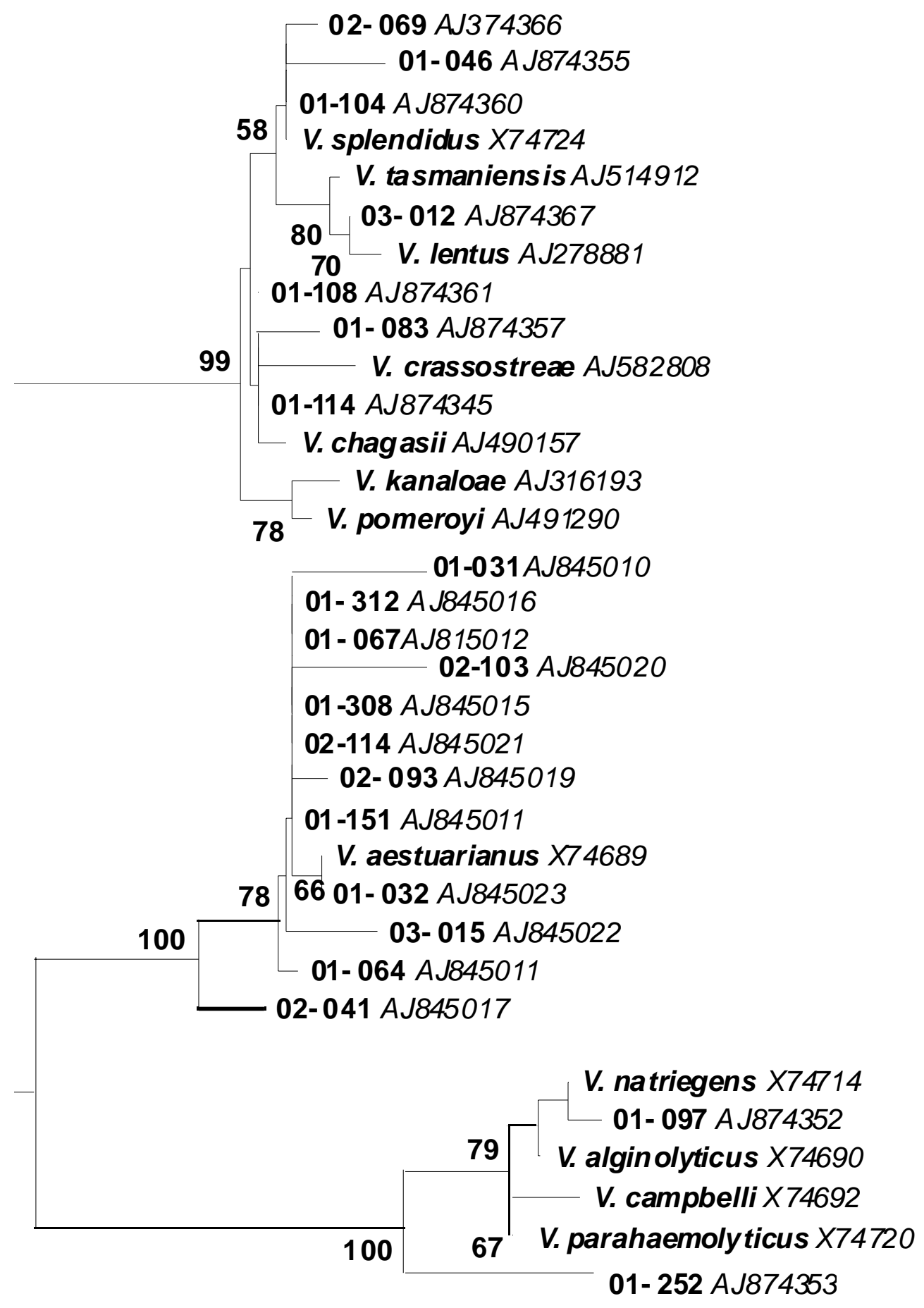


Figure 3. Neighbour-joining tree (global gap removal, mean length 1388) representing the phylogenetic relationship among partial sequences of Pseudoalteromonas isolated from oyster hemolymph and reference Pseudoalteromonas from EMBL sequences data bank. Bootstrap values (500 replicates) greater than $50 \%$ are indicated. Accession numbers of EMBL sequences are given following the name of the isolate. For other legends see figure 2.

P. ruthenica AY723742

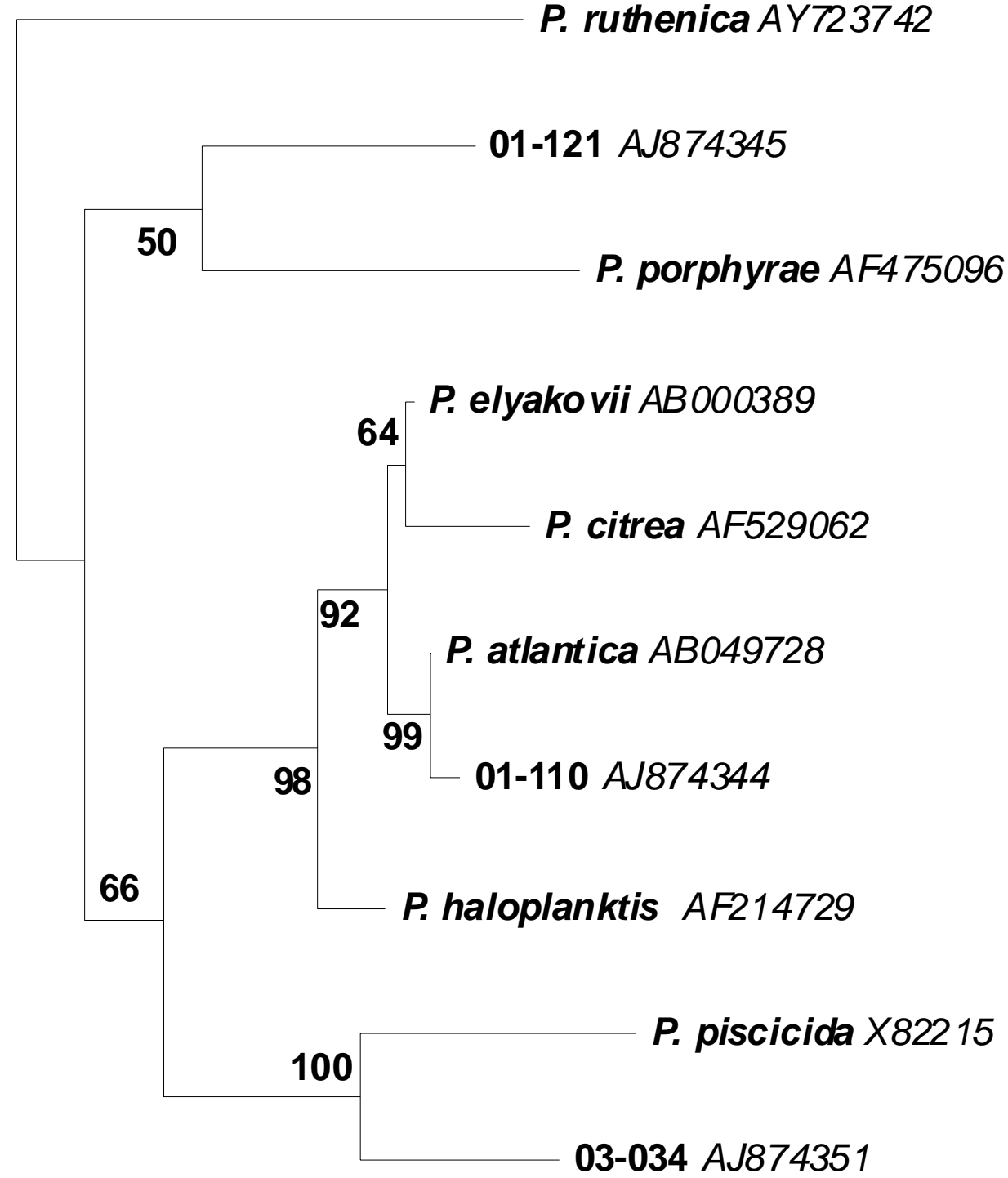




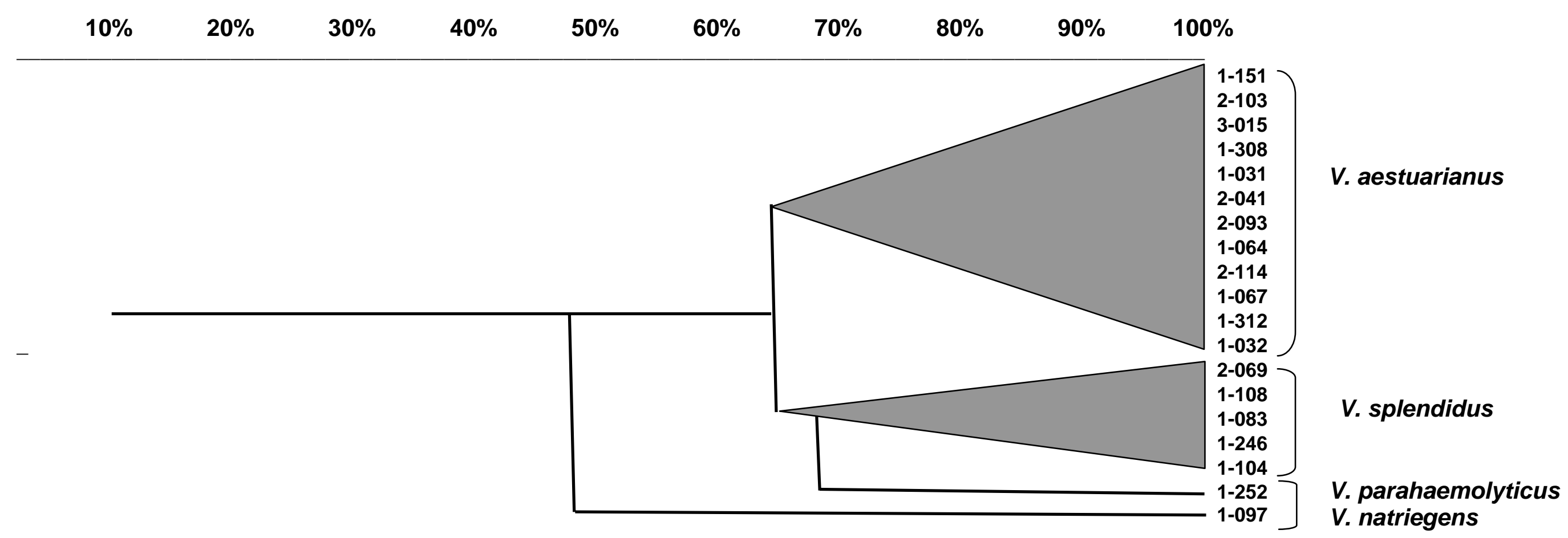

Figure 4. Simplified dendrogram of isolates showing the phena defined with $65 \%$ similitude based on 20 tests. 
Figure 5. Frequency of detection of the different bacterial species isolated in hemolymph of oysters.

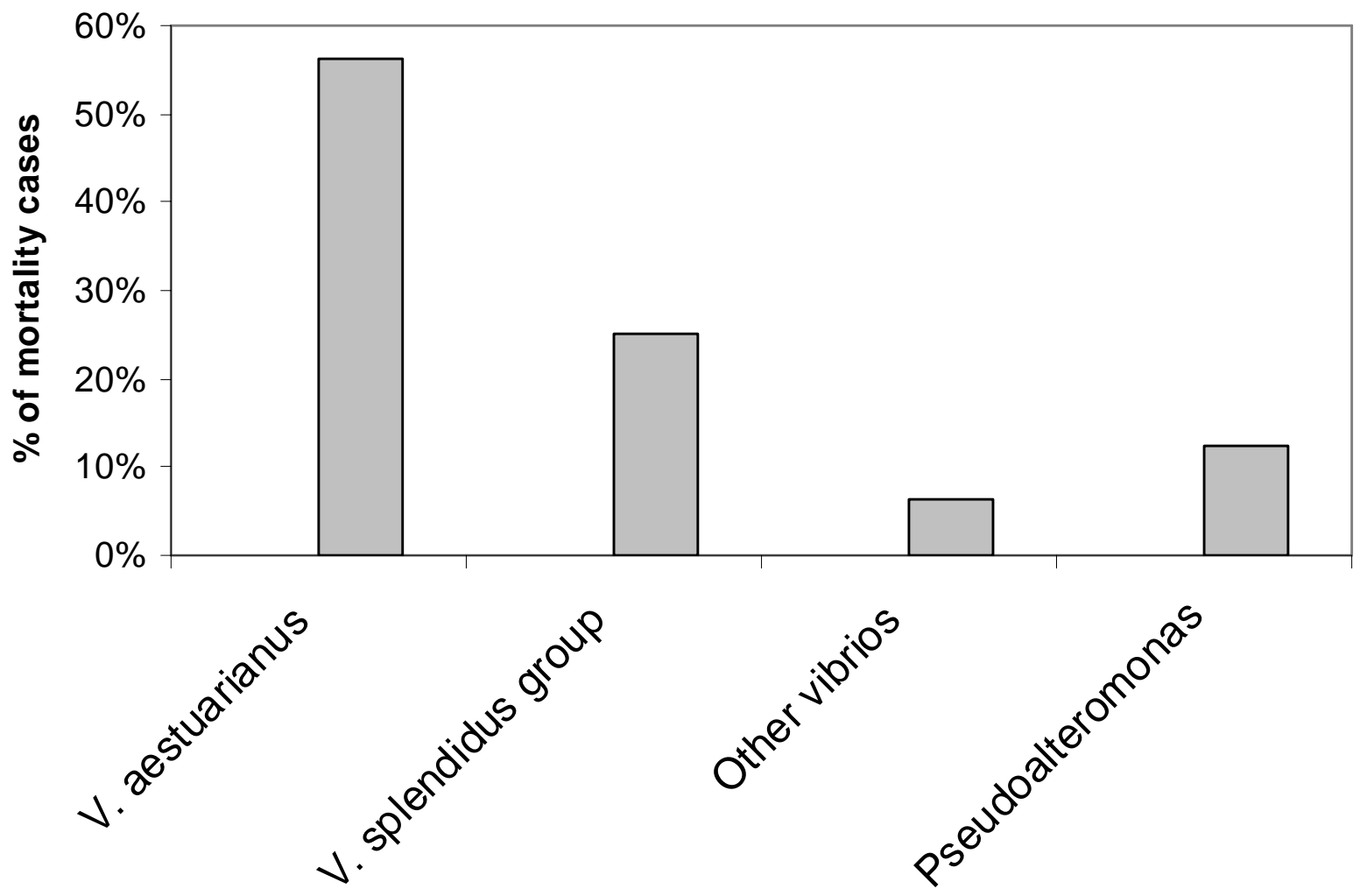


Figure 6. Occurrence of bacteria in healthy oysters (R: resistant families, S: sensitive families) from May to September
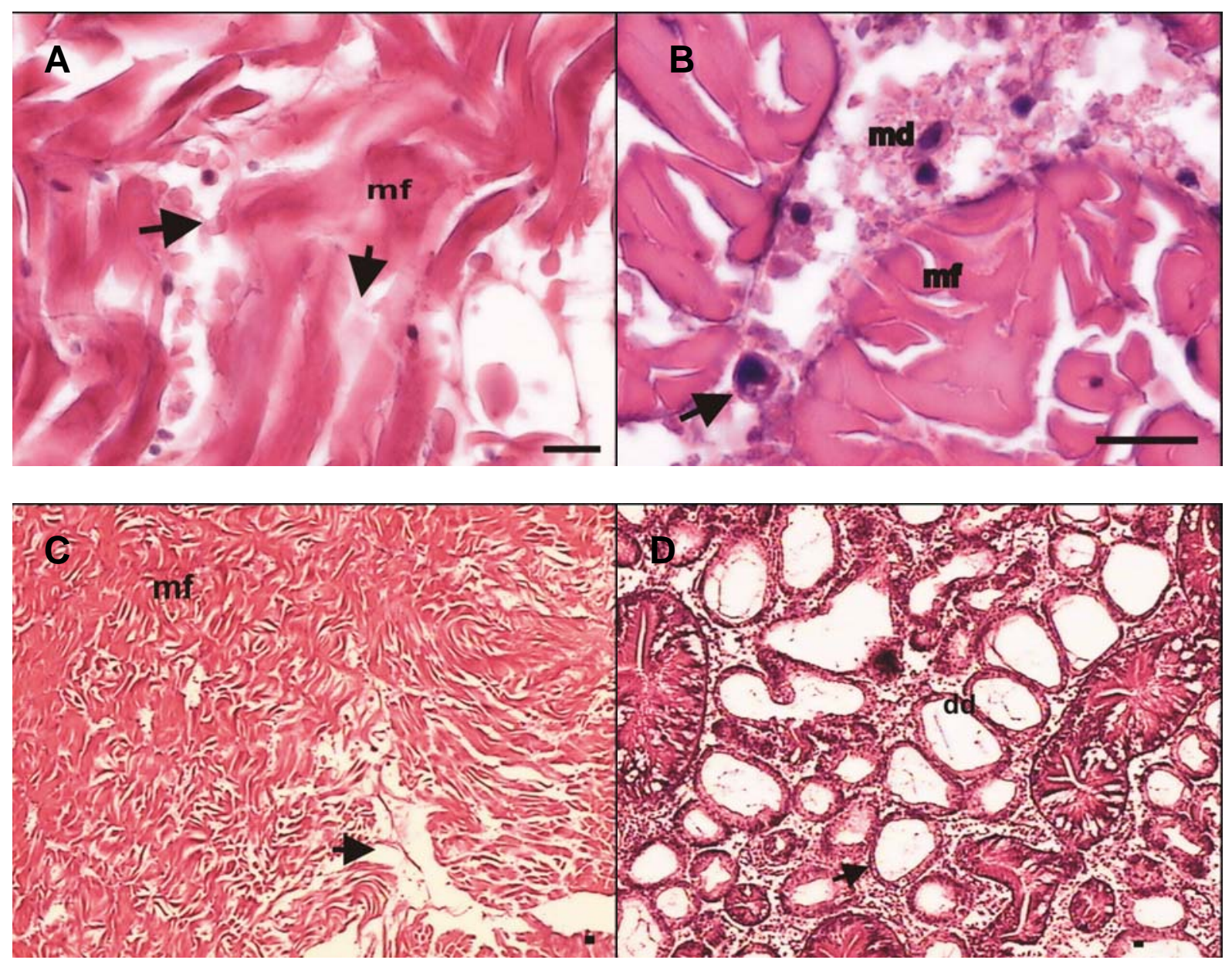